Научная статья

УДК 581.9

DOI 10.18101/2587-7143-2021-4-36-44

\title{
ИНВАЗИОННЫЕ ВИДЫ ВО ФЛОРЕ Г. АБАКАНА
}

\author{
(C) Чеботарева Ольга Петровна \\ аспирант \\ Olga.chebotareva.2014@mail.ru
}

\author{
(C) Антипова Екатерина Михайловна \\ доктор биологических наук, профессор \\ katusha05@bk.ru
}

Красноярский государственный педагогический университет имени В. П. Астафьева Россия, 660049, г. Красноярск, ул. Ады Лебедевой, 89

Аннотация. В статье представлен анализ инвазионных видов во флоре г. Абакана характер которых определяется местонахождением данной территории в лесостепной природной зоне и антропогенным воздействием. Цель изучения - выявление инвазионной фракции флоры г. Абакана. Природные условия города благоприятны для заноса и расселения инвазионных видов растений. Основными путями заноса являются хорошо развитая транспортная сеть, промышленные предприятия, получающие сырье из разных регионов России и ближнего зарубежья, а также различные факторы естественной среды (воздушные, водные течения).

Ключевые слова: г. Абакан, флора, растительность, лес, степь, инвазия, луг, болото, водная растительность, формация, ассоциация, фракция

\section{Для цитирования}

Чеботарева О. П., Антипова Е. М. Инвазионные виды во флоре г. Абакана // Вестник Бурятского государственного университета. Биология, география. 2021. № 4. С. 36-44.

В последнее время изучение городской флоры является одним из актуальных и приоритетных направлений в современной ботанике [1]. Абакан — город в Южной Сибири, городской округ, столица субъекта Российской Федерации Республики Хакасия. Численность населения составляет 171,2 тыс. человек. Город расположен в центральной части Хакасско-Минусинской котловины на высоте 250 м над уровнем моря в устье реки Абакан. По ботанико-географическому районированию Л. М. Черепнина (1957) город расположен в Приабаканском степном районе (C1) [2]. Городская черта простирается с юга и востока по р. Абакан, с запада она разграничена $\mathrm{p}$. Ташеба, а с севера - дамбой, сооруженной для защиты города от подтопления, что обусловливает наличие большого количества растений гигрофильного ряда. Большую роль в формировании растительного покрова города сыграла и ныне продолжает играть сознательная деятельность человека, направленная на оптимизацию городской среды - среды обитания человека. Вследствие этого в парках и по проспектам проводится озеленение не типичными для данной территории видами.

История исследования растительного покрова южной части Красноярского края (включая Хакасию) с 1627 до 1954 г. описана Леонидом Михайловичем Че- 
репниным [3]. История флористических исследований Средней Сибири этого периода времени подробно излагается в работе Н. Н. Тупицыной и др. [4]. Целенаправленных флористических исследований в г. Абакане практически не проводилось. С середины XX в. изучением растительного покрова Хакасии занимается ряд выдающихся сибирских ботаников научных и учебных учреждений Сибири: Томского государственного университета (Томск), Центрального сибирского ботанического сада СО АН СССР (г. Новосибирск, ЦСБС), Красноярского государственного педагогического института (Красноярск, КГПИ) - В. В. Ревердатто, Л. М. Черепнин, А. В. Куминова, А. В. Положий, И. М. Красноборов и др. [5]. Они трудились в течение многих лет и создали свои ботанические школы. Но большинство из них были проездом в г. Абакане. Л. М. Черепниным были собраны интересные растения в г. Абакане в 1942 г. попутно в его экспедиции по Хакасии.

По литературным и данным гербариев, изучением флоры города специально занимались заслуженный деятель РФ И. М. Красноборов и доцент ХГУ Т. М. Зоркина [2]. Иван Моисеевич Красноборов посещал Абакан главным образом проездом в экспедициях по изучению флоры высокогорий Западного Саяна. Он проводил консультации в Хакасском университете и оказывал помощь в определении некоторых видов растений г. Абакана, которые до сих пор хранятся в Гербарии ХГУ $(H G U)$. С 1995 по 2008 г. изучением флоры и растительности Хакасии и юга Красноярского края занималась кандидат биологических наук, доцент ХГУ Т. М. Зоркина [6]. Таисия Михайловна собрала и определила гербарный материал около 250 видов на горе Самохвал, находящейся в черте города, выполнила геоботанические описания.

С 2001 по 2003 г. Абакан посещала Е. Г. Лагунова при проведении диссертационных работ по флоре поймы р. Абакан и ее притоков [7-9]. С 1990 г. по настоящее время исследует флору Хакасии А. Л. Эбель, сотрудник ТГУ в составе экспедиционных отрядов и по гербарным материалам [10]. При изучении биоразнообразия губоцветных во флоре Хакасии (2002-2008) в Абакан заезжает М. А. Мяделец, аспирант Центрального сибирского ботанического сада г. Новосибирска. В 2016 г. в окрестностях г. Абакана гербаризировал сотрудник СФУ Н. В. Степанов.

В 2015 г. была опубликована монография «Степная растительность Хакасии: разнообразие и экология», авторами которой являются А. В. Ларионов, Н. Б. Ермаков, М. А. Полякова, Е. С. Анкипович [11]. В работе представлены результаты многолетнего изучения степной растительности Республики Хакасия.

Несмотря на то, что территория в ботаническом отношении достаточно изучена, сведения об инвазионном компоненте флоры города остаются далеко не полными, что послужило основанием для углубленных исследований его чужеродной фракции.

Цель работы - выявление инвазионных видов во флоре г. Абакана. В связи с этим задачи сводятся к следующему:

1. Изучить историю исследования растительного покрова и краткий очерк растительности г. Абакана, выявить природные условия региона.

2. Определить инвазийные растения во флоре г. Абакана.

3. Выявить их распространение по модельным выделам. 


\section{Материал и методы}

Материалом для работы послужил конспект флоры г. Абакана, составленный на основе коллекции высших растений Гербария им. Л. М. Черепнина (KRAS) КГПУ им. В. П. Астафьева, собранной во время инвентаризации флоры города. Полевые работы проводились методом модельных выделов (МВ) урбанизированного ландшафта совместно с маршрутными изысканиями [9]. В результате территория города была разделена на относительно равновеликие экономикогеографические зоны 250 х 250 м с выраженной экологической и визуальной изоляцией. Пробные площади были заложены в рамках административных границ города, выделялись на основе фитоценотического разнообразия и особенностей антропогенной нагрузки. Таким образом, на территории города было 11 модельных выделов (рис. 1), охватывающих типичные экономико-географические зоны города:

1. Зона жилой застройки (МПС);

2. Промышленная зона (территория Абаканского опытно-механического завода);

3. Парковые зоны (3 модельных выдела: зона отдыха около реки Ташеба (ПкиО), парк Победы, парк Комсомольский);

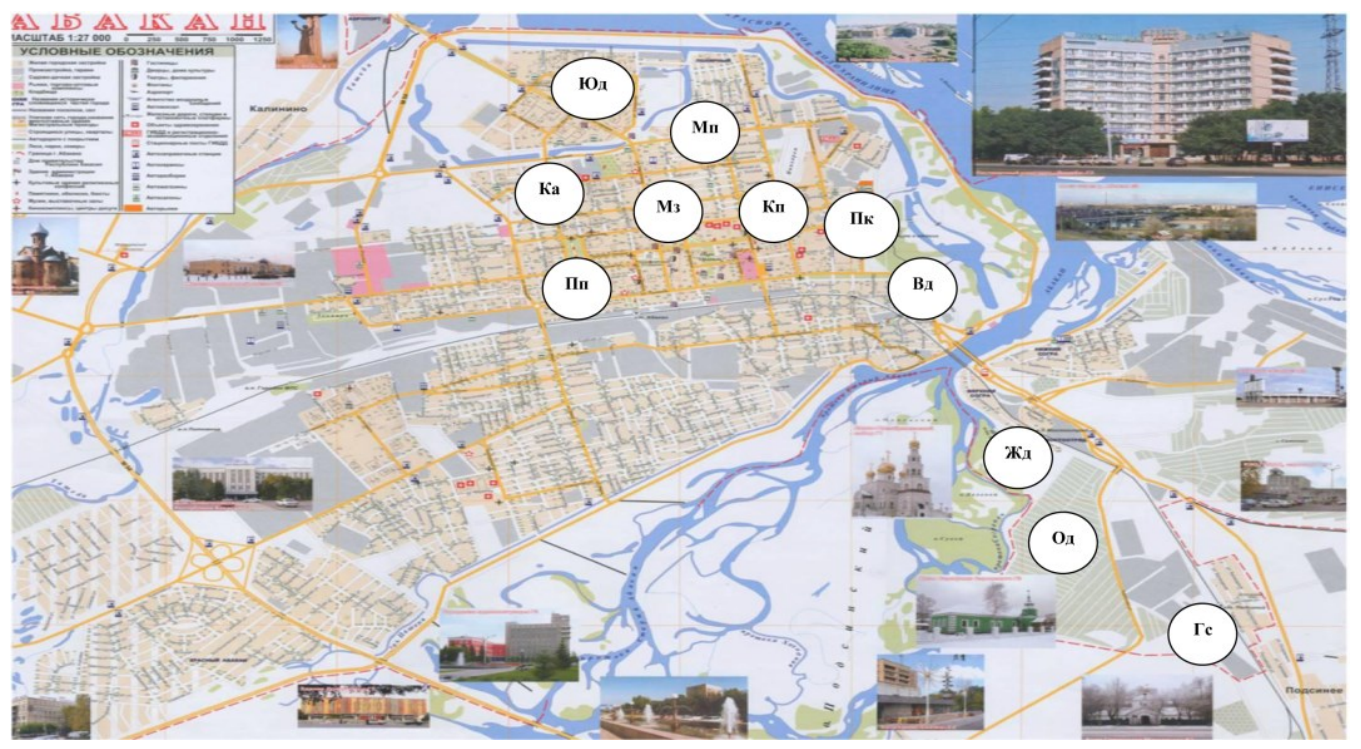

Рис. 1. Модельные выделы — Ка, Мз, ПК, Вд и др. во флоре г. Абакана

4. Берег реки Абакан (2 модельных выдела - восточная дамба, южная дамба);

5. Частный сектор (коттеджи Красный Абакан, Орбитовские дачи);

6. Гора Самохвал;

7. Железнодорожная станция Подсиний.

В работе МВ приводятся в сокращенной форме: Кп - Комсомольский парк, Пк - Парк культуры и отдыха, Мп - район жилой застройки МПС, Ка - коттеджный поселок Красный Абакан, Жд - железнодорожная станция Подсиний, Гс - гора Самохвал, Юд - южная дамба, Вд — восточная дамба, Од - Орби- 
товские дачи, Пп - парк Победы, Мз - территория Абаканского опытномеханического завода.

В 2016-2021 гг. был собран и определен гербарный материал с использованием современных флористических обработок, который позволил провести инвентаризацию сосудистых растений.

Большая часть территорий МВ посещалась неоднократно и в разные сроки вегетационного сезона. В составе MB присутствуют участки естественных местообитаний, находящиеся в городской черте (гора Самохвал, Парк культуры и отдыха возле реки Ташеба и др.), и антропогенные местообитания с нарушенной растительностью: техногенные - территория промышленного предприятия, железнодорожная станция, садово-дачная зона, районы восточной и южной дамб, местообитания жилой зоны (жилая городская застройка и частный сектор) и местообитания искусственных насаждений (парк Победы и Комсомольский парк). Кроме этого, учтены литературные и данные гербариев КГПУ им. В. П. Астафьева $(K R A S)$ и Хакасского государственного университета $(H G U)$. Цитируемые образцы хранятся в Гербарии им. Л. М. Черепнина Красноярского государственного педагогического университета им. В. П. Астафьева.

Результаты и обсуждение

Город Абакан обладает компактной структурой городского центра и протяженной структурой усадебной и дачной застройки ${ }^{1}$. Территория, на которой размещен Абакан, в основном низменная. Лишь с востока и юго-востока равнина окаймлена небольшими возвышениями. Город расположен в местности, где значительную часть занимали топкие болота. На прежнем болоте размещено около шестидесяти процентов современной застройки [12]. Почвенный покров в г. Абакане подвергается интенсивному рекреационному воздействию [13; 14]. Важным фактором воздействия человека на почвенный покров является антропогенная нагрузка. Климат резко континентальный. Летом преимущественно тепло с редкими периодами жары. Зима продолжительная, умеренно суровая [15].

Речная сеть Минусинской впадины представлена системами Енисея и Оби (р. Чулым). Севернее г. Абакана по р. Енисею расположено Красноярское водохранилище. Реки здесь немноговодны, притоков почти нет, только крупные транзитные реки - Енисей, Абакан, Уйбат, Черный Июс и Белый Июс - имеют развитые долины и поймы $[16 ; 17]$.

В современной Минусинской котловине отчетливо выражено два вертикальных пояса - степной и лесостепной. Степная растительность, занимает $47 \%$ всей площади пояса.

Естественная лесная растительность соответствует зональным условиям и сохранилась лишь на окраинах города и внутри некоторых парков. Состав лесообразующих пород невелик.

Степная растительность в черте города сохранилась преимущественно по окраинам города и в зонах жилой застройки. Представлена луговыми и настоящими степями.

Болотная растительность в основном распространена на ограниченных участках города. В основном она приурочена к берегам рек, водоемов. Заболоченные

\footnotetext{
${ }^{1}$ Генеральный план г. Абакана // Решение совета депутатов г. Абакана № 87 с приложением об утверждении Генерального плана г. Абакана. Абакан, 2014.
} 
участки встречаются на южной и восточной дамбе, Парке культуры и отдыха, Красном Абакане.

Прибрежно-водная растительность в г. Абакане встречается в парке культуры и отдыха, Красном Абакане, южной дамбе, восточной дамбах. Выявлено большое разнообразие видов прибрежно-водной растительности.

На территории г. Абакана выявлено 695 видов сосудистых растений, относящихся к 319 родам, 84 семействам. Помимо всех зафиксированных в ходе исследования аборигенных видов растений проанализированы агрокультурные виды, в результате был установлен факт их самопроизвольного внедрения и произрастания, а также потенциально инвазионные виды, способные к возобновлению в местах заноса и проявившие себя в смежных регионах в качестве адвентивных видов. Характерной чертой городской флоры, отличающей ее от флоры естественной, является большая динамичность и непостоянность. Ее состав и общее количество видов могут меняться за достаточно короткие промежутки времени. При этом чем моложе микрорайон, тем более нестабильна его флора. Этому способствуют такие факторы, как расширение застройки, снос старых зданий, развитие промышленности и транспорта.

Сводка инвазионных растений г. Абакана включает 64 инвазионных вида (табл. 1). По уровню агрессивности инвазионных видов и особенностей их распространения среди них выделены: 1) виды «трансформеры», 2) чужеродные виды, активно расселяющиеся и натурализующиеся в нарушенных и полуестественных местообитаниях; 3) чужеродные виды, расселяющиеся и натурализующиеся в нарушенных местообитаниях; 4) потенциально инвазионные виды, способные к возобновлению в местах заноса и проявившие себя в смежных регионах в качестве инвазионных видов.

Таблица 1

Инвазионные виды и их распространение на территории г. Абакана

\begin{tabular}{|l|l|c|l|}
\hline № & \multicolumn{1}{|c|}{ Вид } & $\begin{array}{c}\text { Уровень } \\
\text { агрессивности } \\
\text { инвазионных ви- } \\
\text { дов }\end{array}$ & \multicolumn{1}{|c|}{ Модельные выделы } \\
\hline 1 & Acer negundo L. & 2 & Юд, Вд, Мп, Жд \\
\hline 2 & Amaranthus retroplexus L. & 2 & Пк, Кп, Жд \\
\hline 3 & Amoria hibrida (L.) C. Presl & 3 & Пп, Пк \\
\hline 4 & Bunias orientalis L. & 3 & Кп \\
\hline 5 & Cannabis sativa L. & 2 & Во всех пунктах \\
\hline 6 & Cerasus tomentosa (Thunb.) Yas. Endo & 3 & Пк \\
\hline 7 & Conyza canadensis (L.) Cronq. & 2 & Пп, Кп, Ка, Гс \\
\hline 8 & Echinochloa crusgalli (L.) P. Beauv. & 3 & Гс, Юд \\
\hline 9 & Echium vulgare L. & 2 & Юд, Гс, Пк, Мп, Ка \\
\hline 10 & Elodea canadensis Michx. & 3 & Ка, Юд \\
\hline 11 & Hippophaë rhamnoides L. & 2 & Юд, Од, Пк, Вд \\
\hline 12 & Critesion brevisubulatum (Trin.) A. Löve & 1 & Ка, Пк, Юд \\
\hline 13 & Lepidium ruderale L. & 2 & Гс, Од, Мп, Кп, Пк \\
\hline 14 & Malus baccata (L.) Borkh. & 3 & Пк, Кп \\
\hline 15 & Tripleurospermum perforatum (Merat) M. & 2 & Мп \\
\hline
\end{tabular}


О. П. Чеботарева, Е. М. Антипова. Инвазионные виды во флоре г. Абакана

\begin{tabular}{|c|c|c|c|}
\hline & Lainz. & & \\
\hline 16 & Ulmus pumila $\mathrm{L}$. & 2 & Од, Мп, Ка \\
\hline 17 & Velarum officinale (L.) Rchb. & 3 & Мп, Жд, Кп, Мз \\
\hline 18 & Medicago sativa $\mathrm{L}$. & 2 & Ка, Вд, Кп, Гс, Мп \\
\hline 19 & Pastinaca sy/vestris Mill. & 2 & Юд \\
\hline 20 & Artemisia absinthium L. & 3 & Пк, Вд, Жд \\
\hline 21 & Lepidium draba L. & 3 & Mn \\
\hline 22 & Centaurea scabiosa L. & 4 & $\Gamma \mathrm{c}$ \\
\hline 23 & Chorispora sibirica (L.) DC. & 4 & Мп, Ка, Пп, Ка, Гс, Юд \\
\hline 24 & Saponaria officinalis L. & 4 & Юд \\
\hline 25 & Atriplex patula L. & 3 & $\Gamma \mathrm{c}$ \\
\hline 26 & Atriplex prostrata Boucher ex DC. & 2 & Вд \\
\hline 27 & Teloxys aristata (L.) Moq. & 1 & Ka \\
\hline 28 & Fagopyrum tataricum (L.) Gaertn. & 2 & $\Gamma \mathrm{c}$ \\
\hline 29 & Viola tricolor $\mathrm{L}$. & 4 & Вд, Пк, Од \\
\hline 30 & Brassica campestris L. & 3 & Пп \\
\hline 31 & Brassica juncea (L.) Czern. & 3 & Кп \\
\hline 32 & Camelina sativa (L.) Crantz. & 4 & Од, Гс \\
\hline 33 & Descurainia sophia (L.) Webb. ex Prantl. & 1 & Во всех пунктах \\
\hline 34 & Lepidium latifolium L. & 3 & Гс, Од, Мп, Юд, Пк \\
\hline 35 & Raphanus raphanistrum L. & 4 & $\Gamma \mathrm{c}$ \\
\hline 36 & Sinapis arvensis L. & 4 & $\Gamma \mathrm{c}$ \\
\hline 37 & Sisymbrium loeselii L. & 2 & Во всех пунктах \\
\hline 38 & Tilia sibirica Fisch. & 4 & Кп \\
\hline 40 & Urtica cannabina $\mathrm{L}$. & 3 & Гс, Пк, Мп, Кп \\
\hline 41 & Urtica urens L. & 3 & Пк, Гс, Мз \\
\hline 42 & Ricinus communis $\mathrm{L}$. & 4 & Вд \\
\hline 43 & Sorbaria sorbiflora (L.) A. Braun & 3 & Пк, Ка, Гс \\
\hline 44 & Melilotus officinális (L.) Lam. & 2 & Гс, Пк, Мз, Мп \\
\hline 45 & Erodium cicutarium (L.). L' Her. & 4 & Гc \\
\hline 46 & Hippophaë rhamnoides L. & 2 & Юд, Од, Пк, Вд \\
\hline 47 & Anethum graveolens L. & 4 & Жд, Гс, Од \\
\hline 48 & Anthemis subtinctoria Dobrocz. & 4 & Юд \\
\hline 49 & Centaurea cyanus L. & 3 & Пк, Юд, Гс \\
\hline 50 & Lactuca tatarica (L.) C.A. Mey. & 4 & Вд, Гс, Пп \\
\hline 51 & Sonchus asper (L.) Hill. & 3 & $\Gamma \mathrm{c}$ \\
\hline 52 & Sonchus oleraceus L. & 2 & Жд \\
\hline 53 & Solanum nigrum L. & 3 & Од \\
\hline 54 & Syringa josikaea J. Jacq. ex Reichenb. & 4 & Вд, Мп \\
\hline 55 & Dracocephalum nutans L. & 1 & Встречается повсеместно \\
\hline 56 & Galeopsis bifida Boenn. & 3 & Пк, Юд \\
\hline 57 & Leonurus tataricus $\mathrm{L}$. & 4 & Жд, Ка, Пп, Гс, Пк \\
\hline 58 & Scutellaria scordiifolia Fisch. ex Schrank & 2 & Юд, Вд, Гс, Пп, Ка, Мп \\
\hline 59 & Avena fatua $\mathrm{L}$. & 4 & Мп \\
\hline 60 & Critesion jubatum L. & 3 & Гс, Вд, Кп, Мп \\
\hline 61 & Panicum miliaceum L. & 4 & Мз, Пк \\
\hline 62 & Setaria pumila (Poir.) Roem. et Schult. & 4 & Юд, Гс \\
\hline 63 & Setaria viridis (L.) P. Beauv. & 2 & Гс, Вд, Мп, Ка, Пк \\
\hline 64 & Triticum aestivum $\mathrm{L}$. & 4 & Жд \\
\hline
\end{tabular}


Большая часть общего списка - это виды с невысоким инвазивным статусом (3-4): Bunias orientalis L., Amoria hybrida (L.) C. Presl, Centaurea scabiosa L. и др. Высокие показатели инвазионного статуса (1-2) имеют 23 вида: Acer negundo L., Amaranthus retroplexus L., Critesion brevisubulatum (Trin.) A. Löve, Cannabis sativa L. и др.

Наименьшее количество инвазионных видов растений в г. Абакане встречается на горе Самохвал, в парке культуры и отдыха, южной и восточной дамбах. Эти территории менее всего затронуты урбанизацией, мало жилых домов, машин. В этих местах встречается много естественных зеленых насаждений, отмечается хорошая увлажненность. Климатические и экологические особенности территорий наиболее благоприятны для мезофитов и мезогигрофитов. Между тем среди заносных видов преобладают растения более южного происхождения - выходцы из степных или опустыненно-степных районов: мезоксерофиты и ксерофиты.

\section{Выводы}

Таким образом, во флоре г. Абакана инвазионные виды составляют 9,2\% всей флоры. Природные условия г. Абакана благоприятны для заноса и расселения инвазионных видов растений. Основными путями заноса являются хорошо развитая транспортная сеть, промышленные предприятия, получающие сырье из разных регионов России и ближнего зарубежья, а также различные факторы естественной среды (воздушные, водные течения).

Также стоит отметить, что состав группы потенциально инвазионных видов по мере детального изучения флоры будет постоянно меняться, что связано с дальнейшим расселением многих видов на территории города.

\section{Литература}

1. Антипова Е. М., Кулешова Ю. В. Флора малых городов на примере г. Сосновоборска (Красноярский край, юг Средней Сибири) // Флора и растительность Сибири и Дальнего Востока: чтения памяти Л. М. Черепнина: материалы VI Всероссийской конференции с международным участием (Красноярск, 18-20 мая) / Краснояр. гос. пед. ун-т им. В. П. Астафьева. Красноярск, 2016. С. 58-85. Текст: непосредственный.

2. Антипова Е. М., Чеботарева О. П., Зоркина Т. М. Обзор флористических исследований г. Абакана Республики Хакасия (вторая половина XX века) // Современные биоэкологические исследования Средней Сибири: материалы научно-практической конференции «БИОЭКО» (Красноярск, 26 апреля 2018 г.) / отв. ред. Е. М. Антипова. URL: http://elib.kspu.ru/document/30344/ (дата обращения: 14.09.2021). Текст: электронный.

3. Черепнин Л. М. История исследования растительного покрова южной части Красноярского края // Ученые записки Красноярского педагогического института. 1954. Т. 3, вып. 1. С. 3-80. Текст: непосредственный.

4. Тупицына Н. Н., Сазанакова Е. В. Обзор флористических исследований Хакасии // Вестник Томского государственного университета. Биология. 2015. № 4(32). С. 43-78. Текст: непосредственный.

5. Тупицына Н. Н., Шауло Д. Н., Гуреева И. И. История флористических исследований Средней Сибири: монография. Красноярск: Изд-во Сиб. федер. ун-та, 2017. 226 с. Текст: непосредственный.

6. Зоркина Т. М. Видовой состав, структура и современное состояние степных растительных сообществ Куэстовой гряды в окрестности г. Абакан // Проблемы ботаники Южной Сибири и Монголии: материалы I Международной научно-практической конфе- 
О. П. Чеботарева, Е. М. Антипова. Инвазионные виды во флоре г. Абакана

ренции (Барнаул, 26-28 ноября 2002 г.). Барнаул, 2002. С. 152-158. Текст: непосредственный.

7. Лагунова Е. Г. Конспект флоры лугов долин рек Абакан и Белый Июс // Флора и растительность Алтая: труды Южно-Сибирского ботанического сада. Барнаул: АзБука, 2004. Т. 9. С. 115-147. Текст: непосредственный.

8. Лагунова Е. Г. Реликтовые и эндемичные элементы во флоре лугов долин рек Абакан и Белый Июс // Проблемы ботаники Южной Сибири и Монголии: материалы VI Научно-практической конференции (Барнаул, 25-28 октября 2007 г.). Барнаул: Азбука, 2007. С. 36-38. Текст: непосредственный.

9. Лагунова Е. Г. Флора лугов долин рек Абакан и Белый Июс (Республика Хакасия): диссертация на соискание ученой степени кандидата биологических наук. Новосибирск, 2005. 201 с. Текст: непосредственный.

10. Новые и редкие для Хакасии чужеродные виды растений / А. Л. Эбель, С. И. Михайлова, Т. О. Стрельникова [и др.] // Turczaninowia. 2017. Т. 20, № 1. С. 52-67. Текст: непосредственный.

11. Степная растительность Хакасии: разнообразие и экология / А. В. Ларионов, Н. Б. Ермаков, М. А. Полякова, Е. С. Анкипович. Абакан: Изд-во Хакасского гос. ун-та им. Н. Ф. Катаева, 2015. 194 с. Текст: непосредственный.

12. Торосов В. М. Абакан. 2-е изд. Москва: Цицеро. 1994. 208 с. Текст: непосредственный.

13. Градобоев Н. Д. Природные условия и почвенный покров левобережной части Минусинской впадины // Почвы Минусинской впадины. Москва: Изд-во АН СССР, 1954. С. 7-183. Текст: непосредственный.

14. Горшенин К. П. Почвы горной части Сибири. Москва: Изд-во АН СССР, 1955. 591 с. Текст: непосредственный.

15. Кыров В. В., Кырова С. А. Геоэкологическая оценка рекреационно-ресурсного потенциала урбанизированных территорий (на примере г. Абакана) // Вестник Томского государственного университета. 2008. № 315. С. 220-225. Текст: непосредственный.

16. Мистрюков А. А. Геоморфологическое районирование Назаровско-Минусинской межгорной впадины. Новосибирск: ОИГГМ, 1991. 130 с. Текст: непосредственный.

17. Прокофьев С. М. Природа Хакасии. Абакан: Хакасское кн. изд-во, 1993. 205 с. Текст: непосредственный.

Статья поступила в редакцию 11.10.2021; одобрена после рецензирования 08.11.2021; принята к публикации 06.12.2021.

\section{INVASIVE SPECIES IN THE FLORA OF ABAKAN}

Olga P. Chebotareva

Research Assistant

olga.chebotareva.2014@mail.ru

Ekaterina M. Antipova

Dr. Sci. (Biol.), Prof.

katusha05@bk.ru

Astafyev Krasnoyarsk State Pedagogical University

89 Ady Lebedevoy St., Krasnoyarsk 660049, Russia 
Abstract. The article presents an analysis of invasive species in the flora of Abakan, their nature is determined by the location of this territory in the forest-steppe natural zone and anthropogenic impact. The study is aimed at identifying the invasive fraction of the flora of Abakan. The natural conditions of Abakan are favorable for the introduction and spread of invasive plant species. The main routes of entry are a well-developed transport network, industrial enterprises receiving raw materials from different regions of Russia and the near abroad, as well as various factors of the natural environment (air and water currents).

Keywords: Abakan, flora, vegetation, forest, steppe, invasion, meadow, swamp, aquatic vegetation, formation, association, fraction.

\section{For citation}

Chebotareva O. P., Antipova E. M. Invasive Species in the Flora of Abakan. Bulletin of Buryat State University. Biology, Geography. 2021; 4: 36-44 (In Russ.).

The article was submitted 11.10.2021; approved after reviewing 08.11.2021; accepted for publication 06.12.2021. 